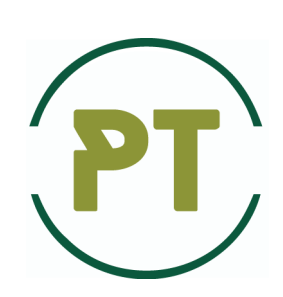

\title{
Analysis of roller designs for sintering and firing machines
}

\author{
O.S. Anishchenko, V.V. Kukhar ${ }^{*}$, A.H. Pryisyazhnyi, I.V. Takhtamysh \\ Pryazovskyi State Technical University (PSTU), Mariupol Ukraine \\ *E-mail:kvv.mariupol@gmail.com
}

\begin{abstract}
The article analyzes the known constructions of roller units of carts for the manufacture of agglomerate and pellets on conveyor lines. The article points out the advantages and disadvantages of roller designs, the lack of standard technical solutions for the design of roller assemblies, as well as reliable methods for calculating their parts for strength and durability. To increase the life of the rollers, the authors, after successful industrial tests, offer innovative technical solutions: seals in the form of stuffing boxes made of expanded graphite fibers reinforced with steel thread; bearing antifriction filler made from polytetrafluoroethylene, carbon fiber and graphite. The article shows that due to axial loads during the operation of the bogies, it is impractical to use ball bearings in the ball, they should be replaced with roller bearings. The authors propose an approximate method for calculating the durability of bearings, which additionally takes into account the elastic deformation of the material of the bogies during their thermal expansion and the gaps in the nodes of the bogies. The authors use the calculation of experimental results on the size of the gaps in the nodes of the bogies, the curvature of the body of the heated bogies on the conveyor line and their movement on three rollers instead of four, take into account the change in the coefficient of linear expansion of the material of the bogie depending on the increase in the heating temperature of the case.
\end{abstract}

Key words: trolley, roller, bearing, seals, clearance, thermal expansion, deflection.

Roller assemblies for pallet and pellet cars are not standardized products, which results in a variety of materials, parts, sizes and relative positions [1-3]. There is an urgent problem in choosing the optimal roller design in the conveyor truck cars for the production of coils and agglomerates.

The roller assembly (Fig. 1) usually contains the following details: traveling and often load rollers; the axis on which the rollers are mounted; bearings for connecting the roller to the axle; end cover of the roller; valve for mechanized lubrication of oil to bearings through the axis of the roller assembly; seals between rollers and axle. The shapes and sizes of the rollers depend on the size of the carts that determines their weight, as well as the mass of the charge and grate. For sintering cars with a sintering area of $2-3 \mathrm{~m}^{2}$, the outer diameter $d x$ and the length $l x$ of the rollers are in the $d_{x}=240-300, l_{x}=120-150 \mathrm{~mm}$. Pellet cars, which have a sintering area of 3-9 $\mathrm{m}^{2}$, are equipped with more massive rollers for which $d_{x}=250-320, l_{x}=150-175 \mathrm{~mm}$. Load rollers are not a necessary component of the roller assembly. Some types of sintering machines use pallet cars without rollers (Fig. 1, a - d). In the cars where the load rollers are present (Fig. 1, e), their dimensions are approximately similar to the dimensions of the rollers. The diameter and length of the axles of the car is calculated, first, for the perception of the forces determined by the mass of the housing and the charge with the grate, and secondly, for the perception of bending moments acting on the sections between the crossbar, in which the hull is pressed one end of the axis, and the bearings rollers mounted on the axis of the press planting. The axle material (steel 20, Art. 3) must withstand these loads at an axis heating temperature up to $180-240{ }^{\circ} \mathrm{C}$. Frequently, in the end surface of the axis axial channels with radial branching are provided to supply the lubricant to the bearings. As a rule, the lubricant is fed into the bearings through the ends of the rollers, therefore in the most cars the ends of the rollers are fitted with valves. Mechanical lubrication is performed by a syringe of a lubricating device that presses inside of the valve the ball and pressurizes the lubricant into the hole formed between the ball and the central opening of the roller cover. 
There are designs of roller assemblies without valves (Fig. 1, a - f), which are used, for example, in TC-2,5 cars at the Dunaferr Iron and Steel Works, Hungary. The covers of the rollers in these structures have no openings and are bolted to the rollers peripherically. Mounting and dismounting of the bolts to remove the cover to lubricate the bearings is time-consuming, so some enterprises (such as the Ilyich Iron \& Steel Works) use covers with a chamomile contour, which is inserted into the groove with the same outline in the roller for fixing on an angle of $60^{\circ}$. The Alchevsk Steel Works pellet cars have round lids that are pressed to the landing end faces of the rollers by the elements made of spring wire with a contour similar to Grover's washer.

Bearings used in roller assemblies, differ in type, material, technology, dimensions, size of individual parts, the presence of one or two rows of balls or rollers [1 - 9]. The number of bearings in the roller varies from one to three. The absence of standards for the roller assembly design indicates the absence of generally accepted cannons of design and the imperfection of methods of calculation of individual parts included in this assembly.

The purpose of the article is to improve the designs of roller assemblies of conveyor cars of sintering and pellet machines that ensure the efficiency and durability of the bearings and seals; clarification of the method of calculating the longevity of the bearings, which operate in the conditions of thermal expansion of the cart bodies.

It is known that the least durable parts of the roller assembly are seals and bearings. In most car designs, labyrinth seals are used (Fig. 1, b) [4], which is a few annular concentric grooves on the end surface of the rollers facing the housing, inside which circular concentric projections or fixed element of the cart are located, usually a crossbar, or adjacent to the traveling roller. Such a seal effectively protects the bearing and the surfaces of the rollers and contacting axes from dust and abrasive particles. However, the labyrinth seal is too laborious to manufacture. In addition, even a small inconsistency of its elements leads to partial or complete jamming of the rollers. The same thing happens when blasting with abrasive dust between the projections and grooves. In some cars, these defects are partially eliminated when replacing the labyrinth seals with elastically deformable elements (such as tubular rubber or polymer) (Fig. 1, d). But such seals are non-durable.

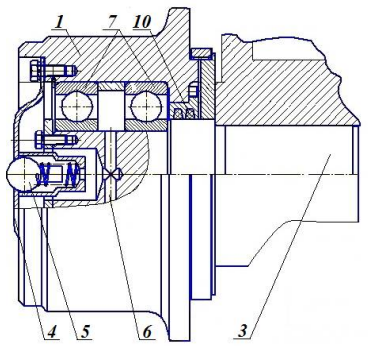

a

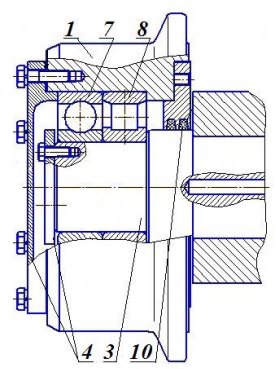

d

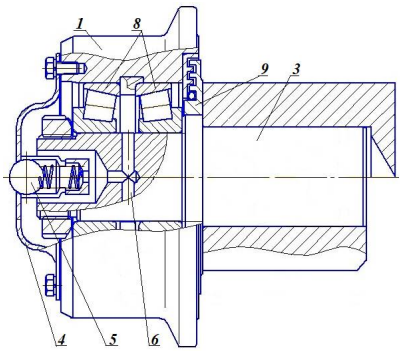

b

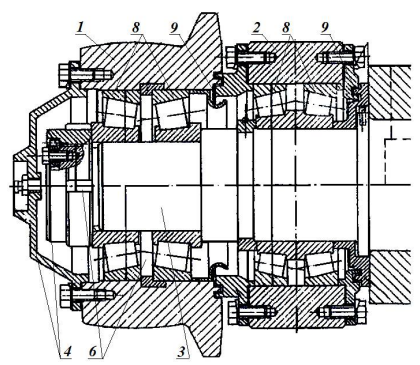

e

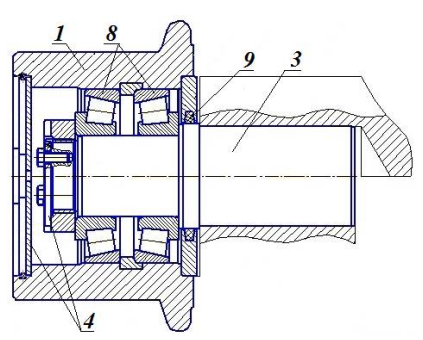

c

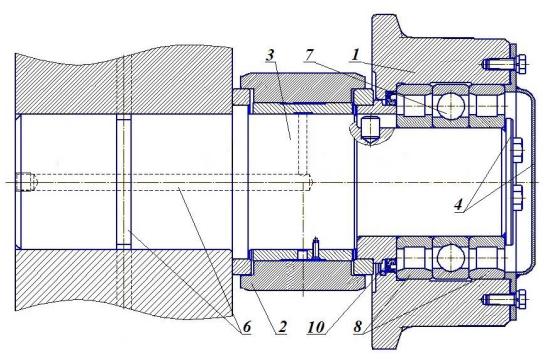

f

Fig. 1 Roller assemblies of pallet and pellet cars:

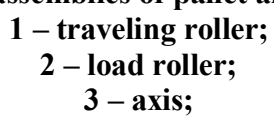

4-cover;

5 - the valve of mechanized lubricating of bearings;

6 - channels for lubrication of bearings;

7 - ball bearing;

8 - roller bearing;

9 - curtain seal;

10 - graphene seal

As an alternative to the existing labor-consuming in manufacturing or non-durable sealing we have tested new types of compression packing [5,6]. Material of stuffing - fibers of expanded graphite, reinforced with steel 
thread, or thermally expanded graphite, filled with carbon nanotubes with an average diameter of 10-20 nm. The packing in the form of a cord of square section with a side equal to 6 or $8 \mathrm{~mm}$ was enclosed in one (Fig. $1 \mathrm{c}$ ) or two (Fig. 1, a, d) annular grooves made on the cylindrical surface of the axes of the cars. The steel threads provided the wear resistance of the cords, and the graphite fibers provided low friction and heat resistance (up to $650{ }^{\circ} \mathrm{C}$ ). The new packing provided a high quality seal of the roller assemblies, which was no worse than a labyrinth, during operation, and functioned at least during the repair period of the carts. When repairing or preventing inspection of the roller assembly, the packings were normally replaced with new ones, although in most cases they were still functional. It should be noted that the replacement time of the gasket was several times shorter than the installation of the elastically deformable elements or the cleaning of the labyrinth seal.

Bearings play an important role in the trouble-free operation of the roller assembly. Their working conditions are rather difficult. At low speed of rotation of rollers bearings have to withstand the raised temperature of heating, the big radial and axial loading. A complex problem is the buildup of sintered particles that fall into the roller when the seal is poor. Among the known reasons for reducing the service-life of the bearings [7], most often, their refusals are fixed due to thermal decomposition or lack of lubricant, as well as contact with sintered particles in the bearing. For the movable joint of a roller with an axle roller and ball bearings of various types and sizes are used. Cargo rollers sometimes use sliding bearings, to which in some cases oil is fed through a duct system with access to the end face of the axle facing the car hull (Fig. 1, e). Recently, caprolone and polyamide have been well established as sliding bearing materials [1].

As a rule, two roller bearings are installed in the inner holes of each roller. In large pellet cars up to $6 \mathrm{~m}$ wide (Mikhailovsky, Lebedinsky GOK, as well as GOK "Karelian pellets"), two roller bearings are pressed into rollers and one ball bearing between them (Fig. 1, e). The unit provides for the installation of an outer ring of the radial ball bearing in the bore of the housing roller with a gap in diameter [8], which increases the overall service life of the roller assembly. It is easier to operate the ball bearings (Fig. 1, a, TS-2.5, US Steel, Kosice), but they are not intended to accommodate the axial loads arising from the thermal expansion of the cars during operation, the deflection of their housings and warp of the carts when they are moving along the belt of the sintering or pellet machine. Roller bearings are able to handle axial loads, but they are more expensive and require adjustment during operation.

Nowadays the best cylindrical and conical roller bearings with self-installing rings at many enterprises are those, which are commercially available by NSK (Fig. 2) and are its intellectual property [9].

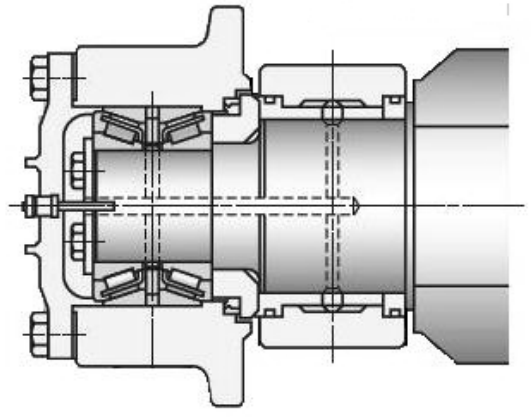

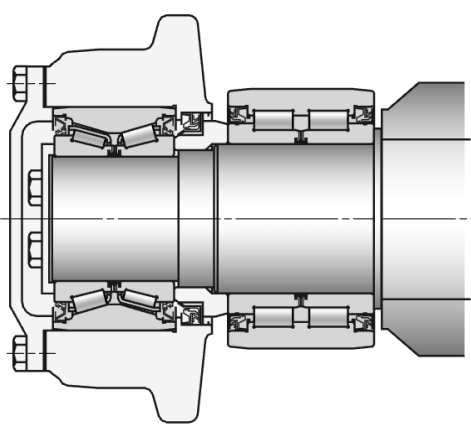

b

Fig. 2 Roller knot assemblies for NSK bearings: traditional (a), new construction (b)

The designs of the bearings have embodied a number of innovative solutions of the company. In particular, a special contact seal was applied, which allowed the lubrication of the bearings to be avoided through a system of holes in the axis and a valve at the end of the roller. There is no separator in the bearings, ie the bearing is filled with rollers, which provides high load capacity. More efficient bearing operation is facilitated by a special bending on the rolling paths and a thicker outer ring. The optimum convexity of the roller track surface helps to keep the rollers to be sufficiently strong, even with unbalanced loading. The integral design with the mounting ring provides easier installation and disassembly of the bearing. Oil resistant to temperature and pressure is used. The company declares a threefold increase in the stability of such bearings compared to the designs of other competitors. However, the cost of such bearings is $2-3$ times higher than that of similar-sized domestic bearings; Preference is given to improving the design of roller assemblies in the direction of selection and supply of lubricant to bearings, as well as to increase the efficiency of seals. In our view, the forced flow of liquid lubrication into the bearings through the holes in the axes has exhausted itself intellectually and innovatively. More promising solutions are bearings with quasi-solid anti-friction fillers.

Specialists of Ilyich Iron \& Steel Works, in cooperation with Metalon Products (Canada), to reduce the wear and friction in the bearings of the cars, created a new grease LSC-16 M-IS [10]. Unlike analogues, this lubricant chemically combines with the molecules of the metal components, forming a microscopic, 
monomolecular, wear-resistant, protective layer. Periodic opening of the rollers of the carts during their operation showed that the oil retains its mechanical properties. There are also no traces of oil carbonization, no separation of the base from the thickener. The bearings are in working order, have no chips or burrs on the working surface. The use of lubricant eliminates the additional pumping of the lubricant into the rollers when operating machines using mobile stations and hand pumps.

In industrial conditions, roller assemblies of pellet carts were tested for bearings with wooden particles (Russia), fillers on polymer composite materials base (PCM) and graphite (Belarus). Wooden particle fillers for the car bearings proved to be of little use. If during normal operation of pellet machines such bearings functioned without any failures, any violation of the technology that caused the machine to stop, that is, the settling of part of the carts under the hearth led to overheating and sintering of the filler in the bearings with their subsequent jamming. The heating of the rollers at standing under the hearth reached $170-200{ }^{\circ} \mathrm{C}$, which caused the heating of the bearings to a temperature above $90{ }^{\circ} \mathrm{C}$ - the critical operating temperature of the wood filler. Antifriction fillers of Belarusian production with good performance in the normal mode also did not withstand the resistance of the carts under the hearth. In this case, the filler, when heated, thinned and leaked out of the bearing separators, which quickly failed without lubrication.

According to our data, ball bearings with a solid, lubricating, antifriction filler. When choosing a bearing protection material, its anti-friction and physical-mechanical properties, heat resistance, resistance to corrosive media, processability were considered. For this reason, polytetrafluoroethylene was chosen as the matrix for PCM creation. But along with the complex of unsurpassed properties (high thermal and chemical resistance, low friction coefficient, etc.), pure polytetrafluoroethylene has low durability and durability, therefore, a hybrid filler - carbon fiber and graphite [11] was used as a filler. For industrial testing, single-row ball bearings 315 were used. The technology of the solid propellant PCM bearing included hydrostatic extrusion of the filler previously placed on the serpentiform separator at temperatures 50 - 100 degrees below the outlet temperature of the bearing ring material. Immediately after pressing, the bearing rings were rotated relative to each other for the bearing balls to form a rolling path in the filler. The use of antifriction filler in the bearing ensures optimum friction conditions, reduces abrasive wear and the heating temperature of the bearing. These advantages can be provided if the filler, located on the serpentiform separator, does not change the radial and axial gaps between the rolling bodies and the rings, as well as tangential gaps between the rolling bodies and the separator. Otherwise, there is a redistribution of load between the bearing components, which reduces the bearing service life.

The manufactured bearings were tested on different types of cars operated at different sinter factories of Ukraine and Russia. Test results are presented in the table and indicate that AFF bearings serve $2-2.5$ times longer than standard ones. The limiting factor causing the failure of the AFF bearings was the lack of strength of the PMC filler. Works on improvement the performance of the bearings by using nanocomposites as a filler, including fullerene cells are planned for the future[12].

\section{Comparative performance of bearings}

Table 1

\begin{tabular}{|c|c|c|c|c|}
\hline \multirow{2}{*}{ Bearing } & \multirow{2}{*}{ Type } & \multicolumn{3}{|c|}{ Service life in months while applied at pellet cars } \\
\cline { 3 - 5 } & & TC-2,5 & TC-2,7 & TC $-2,7$ \\
\hline \multirow{2}{*}{315} & standart & $3-4$ & $3-5$ & $3-5$ \\
\cline { 2 - 5 } & With AFF & $7-10$ & $8-10$ & $7-9$ \\
\hline
\end{tabular}

Given the results of industrial testing of bearings operating in roller assemblies of the cars, it is advisable to determine the possibility of predicting these results by analytical methods. First, we determine the bearing service life by the standard method $[4,7]$. The calculation is performed by the formula:

$$
L_{o}=a_{1} \cdot a_{2} \cdot a_{3} \cdot\left(\frac{C_{d}}{P}\right)^{p},
$$

where $L_{o}$ - rated durability, mln rpm;

$a_{1}$ - correction factor of reliability;

$a_{2}$ - material correction factor;

$a_{3}$ - correction factor of working conditions;

$C_{d}-$ dynamic bearing capacity, $\mathrm{kN}$;

$P$ - equivalent bearing load;

$p$ - exponent [4].

The loaded TC-2.5 cars with a total mass of 7 tons $(2.95 \mathrm{t}$ is the weight of the car, $0.8 \mathrm{t}$ is the weight of the grate, $3.25 \mathrm{t}$ is the mass of the sintering charge on the car at a layer height of $400 \mathrm{~mm}$, the load on the housing and, therefore, we do not consider the thinning bearings under the grate) are equipped with eight 315 ball bearings, for which [4]: $C_{d}=112 \mathrm{kN}$, static load capacity $C_{o}=72,5 \mathrm{kN}, p=3$. In the ideal case, there is a 
radial load, which is evenly distributed into 8 bearings, each of which receives a force equal to 70,000 N/ $8 \sim 9 \mathrm{kN}$. The axial load is absent. Therefore, $P=9 \mathrm{kN}$ and

$$
L_{o}=1 \cdot 1 \cdot 1 \cdot\left(\frac{112}{9}\right)^{3}=1925, \mathrm{mln} \mathrm{rpm}
$$

Service life is calculated by the formula:

$$
T_{0}=\frac{L_{0}}{\Pi B \cdot \Phi \cdot n \cdot 60}, \mathrm{yrs},
$$

where $\Pi B$ - duration of powering on the sinter machine, $\Pi B=0,95$;

$\Phi$ - effective annual fund of time of operation of the machine, $\Phi=7800 \mathrm{hrs}$;

$n$ - angular velocity of the bearing, $n=6 \mathrm{~min}^{-1}$.

Then ideally, the bearing service life will be: $T_{o}=721 \mathrm{yrs}$.

In real-world conditions, the car bearings work in very difficult conditions that reduce their service life: high dustiness, which causes premature abrasive wear of the bearing; the influence of high temperature from the sintering of the charge on the grate, which warms the bearing to $40-80{ }^{\circ} \mathrm{C}$; constrained standing of the car under the hearth (under the flame torch acting on the surface layer of the sinter shaft); such resistances, associated with breaks in the sintering process and line stopping, take from 5 to $15 \%$ of the time of operation of the sinter machine; a half-hour stand up of the cart under the hearth can warm the bearing up to $200{ }^{\circ} \mathrm{C}$, which will result in practically complete leakage of oil from it and its further operation in conditions of dry friction; significant axial load on the bearing caused by the temperature expansion of the car hull; these loads are transmitted from the housing through the bolt and the axle pressed into the bolt hull to the end face of the outer ball bearing ring and significantly exceed the radial loads; in addition to the axial loads, the bending moments from these loads are transmitted to the axle and bearings, since the axles are often located below the lower ends of the car hull.

Due to thermal stress, the car hull is deformed (bending down to $20 \mathrm{~mm}$ and slight curvature in the form of twisting). Due to the twisting, most carts are moved along a conveyor line on three rollers. Then the radial load on each of the six bearings increases to $P_{0}=70000 \mathrm{H} / 6 \sim 12 \mathrm{kN}$.

The temperature expansion of the car hull happens since its upper part, in contact with hot grate, is heated to 800 , and the lower - to $200{ }^{\circ} \mathrm{C}$. The calculation of increasing the $\mathrm{Z}$ length of the hull of the car is calculated by the formula:

$$
Z=Z_{0} \cdot(1+\beta \cdot t)
$$

where $Z_{0}$ - output hull width equal to $2000 \mathrm{~mm} ; t$ - average temperature rise when the car hull is heated, which is assumed to be even $500{ }^{\circ} \mathrm{C} ; \beta$ - temperature coefficient of linear expansion of the hull material,

Parameter $\beta$ is calculated by the formula [17]:

$$
\beta=10^{-6}\left[a_{0}+a_{1}\left(\frac{t}{1000}\right)+a_{2}\left(\frac{t}{1000}\right)\right]
$$

where $a_{0}, a_{1}, a_{2}$ - coefficients; for steel $09 \Gamma 2 \mathrm{C}$;

$a=10,6 ; a_{1}=12$;

$a_{2}=0$.

Accordingly, $\beta=16,68 \cdot 10^{-6} \mathrm{deg}^{-1}, Z=2016,7 \mathrm{~mm}$.

Assuming that the deformation of the hull occurs in the elastic region, we calculate the $\sigma$ stress by the Hooke's law, where the stress is caused in the body of the hull and which is transmitted to the end surface of the outer rings of bearings, then - to the surface of the flange of four rollers resting on the heads of the rails:

$$
\sigma=E \varepsilon,
$$

where $E$ - Young's modulus for hulls materials (steel St.52-3), under normal conditions $E=210 \mathrm{GPa}$;

$\varepsilon-$ the degree of deformation of the hull.

Parameter $\varepsilon$ is calculated by the formula: $\varepsilon=\left(Z-Z_{o}\right) / Z_{o}=8,35 \cdot 10^{-3}$.

Given that the hull is on average heated to $500{ }^{\circ} \mathrm{C}$, the Young's modulus for such temperature is, according to [18], $0.35 \cdot E=73.5 \mathrm{GPa}$, Then $\sigma=614 \mathrm{MPa}$. This voltage is transmitted through a two-inch crosssection of the longitudinal beams of the hull on the crossbar, then on the axle, the bearings and the ridges of the roller. The three-slotted hull design has 4 longitudinal beams with a total cross-sectional area equal to $4 \cdot 10^{-2} \mathrm{~m}^{2}$. The total force $\left(614 \mathrm{MPa} \cdot 4 \cdot 10^{-2} \mathrm{~m}^{2}=24560 \mathrm{kN}\right)$ on each side is perceived by 4 bearings, each of which has an axial force $P_{o c}=24560 / 4=614 \mathrm{kN}$. 
The equivalent dynamic load in the presence of axial force is calculated by the formula:

$$
P=X V P_{p a d}+Y P_{o c}
$$

where $P_{\text {rad }}-$ radial stress on bearing, $\mathrm{kN}$;

$X, V, Y$ - coefficients.

According to [4], for the case under consideration, $V=1,2, Y=1$. For the maximum ratio $P_{o c} / C_{0}=0,56$ coefficient $X=0,44$. In our case $P_{o c} / C_{0}=8.53$, that is, the coefficient $X$ is determined by extrapolation and exceeds 1 , in which case we take $X=1$. Then: $P=1 \cdot 1,2 \cdot 12+1 \cdot 614=628 \mathrm{kN}$ and the durability of $L$ will decrease to:

$$
L=1 \cdot 1 \cdot 1 \cdot\left(\frac{112}{628}\right)^{3}=5671
$$

that is, the bearing service life will be $T_{o}=5671 / 0,95 \cdot 7800 \cdot 6 \cdot 60=0,025$ months.

Thus, the calculations show that due to the thermal expansion of the hull, considerable axial forces acting on the ball bearings occur. The correlation between radial and axial forces exceeds the critical values [4], which makes the use of ball bearings in spherical carts impractical because of their short service life. However, in real life, these bearings run longer (see table). The reason for the discrepancy between the calculation and the operational data is the gaps in the assemblies of the cars and between the car and the track of the sinter machine conveyor. At thermal expansion of the hull of the car, these gaps are chosen first, and then there are elastic deformations and associated stresses in the assemblies of the car. The absolute magnitude of the elastic deformations is reduced by the total value of the gaps. Consequently, the stresses and axial forces on the bearings are reduced. For example, the maximum deviation of the width of the hull of the car, which is 2000 $\mathrm{mm}$, by $-I T 16 / 2$ quality is $3 \mathrm{~mm}$ per side. The one-sided clearance between the roller flange and the conveyor belt rail head, caused to a large extent by the wearing out of the head and partly the wearing out of the flange surface, reaches $5 \mathrm{~mm}$. This gap is also increased by $1-5 \mathrm{~mm}$ due to the deflection to a depth of up to $20 \mathrm{~mm}$ of the car hull under the action of its own weight and the weight of the socket. On average, the total bilateral clearance can reach $u=2(1.5+2.5+3)=14 \mathrm{~mm}$.

Then the elastic deformation will decrease to a value equal to

$$
\varepsilon=\frac{Z-\left(Z_{0}+u\right)}{Z_{0}+u}=\frac{2016,7-(2000+14)}{2000+14}=1.34 \cdot 10^{-3},
$$

which will reduce the stress to $\sigma=73.5 \cdot 10^{3} \cdot 1.34 \cdot 10^{-3}=98,49 \mathrm{MPa}$.

Further calculations show that in this case, the bearing service life increases to 6.6 months. This figure is twice the actual life of the standard bearing in the car, but it defines the bearing service life with the anti-friction filler quite accurately (see table above). Comparing the actual and estimated values of the ball bearing durability, it can be stated that the calculated values are a lower estimate of the service life of the anti-friction bearing.

Recently, roller bearings 7315 have been installed in the cars of TC-2,5 of the US Steel mill instead of the ball bearings 315. [4]. For these bearings $C_{d}=180 \mathrm{kN}$, static load $C_{o}=148 \mathrm{kN}, \alpha=12^{\circ}$, exponent in equation (1) $p=3,3[4]$.

The nominal durability of these bearings according to equation (1) is:

$$
L_{o}=1 \cdot 1 \cdot 1 \cdot\left(\frac{180}{9}\right)^{3,3}=19652 \mathrm{~m} \ln \mathrm{rpm}
$$

The axial load on the bearings according to the formula (2) assumes the values of the coefficients $V=1.2$; $X=\operatorname{tg} \alpha=0.213 ; Y=1$. Then the equivalent load on the bearing will be $P=0.213 \cdot 1.2 \cdot 12+1 \cdot 614=617 \mathrm{kN}$ and durability will decrease to:

$$
L=1 \cdot 1 \cdot 1 \cdot\left(\frac{180}{617}\right)^{3,3}=7160 \mathrm{rpm},
$$

that in months of work will be $T_{0}=17160 / 0.95 \cdot 7800 \cdot 6 \cdot 60 \sim 0,08$ months

A similar conversion of the service life of the roller bearings, considering the size of the gaps, gives an increase in the service life of 0.08 months up to 30 months. When the average service life of the roller bearings of 8-12 months, the obtained data indicates the inappropriate use of the above given calculations to predict the durability of the roller bearings of the car. First, this refers to the narrow range and the apparent imperfection of the selection of the table coefficients in equation (2). 


\section{Conclusions}

The use of roller bearings with antifriction filler based on polytetrafluoroethylene and fibers of expanded graphite on the pellet and pallet cars allows to reliably protect the bearing from abrasive dust, reduce friction during rolling and increase its durability in 2 - 2,5 times. As a result of the temperature expansion of the hull, axial loads significantly exceeding the radial loads are exerted on the roller assembly bearings during the operation. As a rule, these loads exceed the maximum permissible axial forces for radial ball bearings, so their use in roller cars is unreasonable. An approximate method of calculating the durability of bearings is proposed, which considers the elastic deformation of the material of the car with thermal expansion and the size of the gaps in the assembly units of the car. The results of the calculations may serve as a lower bound for the evaluation of the durability of ball bearings with anti-friction filler. For roller bearings, the calculated durability indices are 2.5 - 4 times higher than the actual results.

\section{References}

1. Lovchinovsky E. V. Mekhanicheskoe oborudovanie fabric dlya okuskovyvsnya zhelezorudnogo syrya. / E. V. Lovchinovsky. - Moscow: Metallurgy, 1977. - 256 s.

2. Kokorin L. K. Proizvodstvo okuslennykh okatycheu. / L. K Kokorin, S. N. Llelko. - Ekaterinburg: UTsPRsR "Marat", 2004. - 280 s.

3. Mashinistroenie: entsyclopediya v 40 tomakh. Tom IV-5. Mashiny I agregany metallurgychskogo proszvodstva. Pod red. V. M. Sinitskogo,, 1992. - 608 s. N.V. Pasechnika. - M.: Mashinostroenie, 2000. - 921 s.

4. Perel A.Ya. Podshipniki kachenya. Raschen, proektirovanye I obsluzhivanye opor: Spravochnik. / A.Ya. Perel, A.A. Filatov. - M.: Mashinistroenye

5. OOO "TMSpetsmash". Luchshie uplotnenya dlya promyshlennosty ot otechestvennogo proszvoditelya. [Elektronnyi resurs].- nabivka.com.

6. IZOLA. Promyshlennye izolyatsionnye materialy. [Elektronnyi resurs].- izola.com.ua.

7. Kravchenko V. M. Tekhnichne diagnostuvannya mekhanichnogo obladnannya. Pidruchnyk./ V. M. Kravchenko, V. A. Sidorov, V.Ya. sedush. - Donetsk: TOV “Yugo-Vostok”, 2007. - 447 s.

8. Patent 2299130 RF Podshipnikoyi uzel koveyenoylinyi./ D. N. Doronin [i dr];. OOO "UralmashMetallurgicheskoye oborudovanie”. - Opubl. 20.05.2007, Bul. No19..

9. Podshipniki dlya metallurgicheskoy promyshlennosty NSC. [Elektronnyi resurs].- www.retmaster.ru.

10. Smazochnye materialy i prisadki. [Elektronnyi resurs] - metalon.com.ua

11. Burya A. I. Tverdosmazyvayushchaya zashchita podshipnika kachenya. / A. I. Burya, V. Yu. Dudin, A. Yu. Vankov.// Oborudovanie I instrument. Serua "Metalloobrabotka", 2006. - No2. - S.17-21.

12. Burya A. I. Issledovanie svoystv nanokompozitov na osnove aromaticheskogo poliamida I fullerenovoy cherni. / A. I. Burya, O. Yu. Kuznetsova // Vestnik KhNadu.-2010.-No51.- S.96-99.

13. Anishchenko, A. S. Rotary flaring of faceted flairs on pipe blanks. / A. S. Anishchenko, // A. P. Andryushchenko.// Soviet Engineering Research.-1991.- No11(5), S. 95-97.

14. Anishchenko, A. S. Hot expansion of precise ring forgings./ A. S. Anishchenko, Yu. V. Feofanov, A. B.

Bogun, // Khimicheskoe i Neftegazovoe Mashinostroenie.- 1992.- No11, S. 33-35

15. Anishchenko O.S. Analysis of the Sheet Shell's Curvature with Lame's Superellipse Method during Superplastic Forming./ O. S. Anishchenko, V. V. Kukhar, A. V. Grushko, I.V. Vishtak, A.H. Prysiazhnyi.// Materials Science Forum.-2019.- 945, S.531-537.

16. Anishchenko A. Application of G. Lame's and J. Gielis' formulas for description of shells superplastic forming./ A. Anishchenko, V. Kukhar, V. Artiukh, O. Arkhipova.// MATEC Web of Conferences.2020.- 239, 06007.

17. GOST 8.586.1-2005. Izmerenyi raskhoda I kolichestva zhidkostey I gazov s pomoshchyu suzhayushchikh ustroistv.

18. Drapkin B. M Svoistva splavov v ekstremalnom sostoyanii./ B. M. Drapkin, V. K. Kononenko, V. F. Bezyazychnyi.- M.: Mashinostroenye, 2004. -256 s.

Анищенко А.С., Кухарь В.В., Присяжный А.Г., Тахтамыш И. В. Анализ конструкций роликов агломерационных и обжиговых тележек.

Рассмотрены известные конструкции роликов тележек для изготовления агломерата и окатышей. Определены преимущества и недостатки конструкций роликов. Предложены инновационные технические решения по увеличению срока эксплуатации роликов: уплотнение в виде сальниковых набивок из волокон вспученного графита, армированных стальной нитью; антифрикционный наполнитель для подшипников, созданный из политетрафторэтилена, углеродного волокна и графита. Показано, что из-за осевых нагрузок при эксплуатации тележек нецелесообразно использовать шарикоподшипники в роликах, их следует заменять на роликоподшипники. Предложен приближенный метод расчета долговечности подшипников, учитывающий упругую деформацию материала тележек при тепловом расширении и величины зазоров в узлах тележек.

Ключевые слова: тележка, ролик, подшипник, уплотнения, зазор, тепловое расширение, прогиб. 